\title{
NOTE
}

\section{Quantifying hermit crab recruitment rates and megalopal shell selection on wave-swept shores}

\author{
S. E. Worcester ${ }^{\circ}$, S. D. Gaines \\ Marine Science Institute and Dept of Ecology, Evolution and Marine Biology, University of California, Santa Barbara, California 93106, USA
}

\begin{abstract}
The availability of shells has been shown to limit populations of adult hermit crabs and alter the outcome of interspecific interactions. However, few studies have addressed such issues in newly settled crabs. A major impediment has been the absence of techniques to quantify the use of shells by settling crabs. Here we present a simple technique for assessing hermit crab recruitment in rocky habitats. The method appears to measure differences in settlement rates among sites without substantial bias. By offering several different species of microgastropod shells, we also found that settling Pagurus hirsutiusculus have distinct shell preferences. Such shell preferences may lead to resource limitation at the juvenile stage which may have cascading effects on the distribution, abundance, or shell use patterns of adult hermit crabs.
\end{abstract}

KEY WORDS: Recruitment - Hermit crab - Pagurus hirsutıusculus Shell limitation

Hermit crabs typically are selective in their use of shells (e.g. Vance 1972, Bertness 1980, Hazlett 1981, Mesce 1993, Gherardi et al. 1994, Elwood et al. 1995). In part because of preferences for different shell species, limitations in the abundance of those shells can greatly affect hermit crab populations (e.g. Bollay 1964, Kellogg 1976, Scully 1979). Although there have been many studies on hermit crab shell preference and shell limitation, these studies have focused almost exclusively on adult hermit crabs. Hermit crab megalopae settling from the plankton also must find shells. Yet few studies have quantified the patterns of hermit crab settlement in the field. If small shells are limiting to settling hermit crabs, then patterns of distribution and abundance of hermit crabs may be established long before the adult stage (e.g. see Asakura 1991).

\footnotetext{
- Present address and address for correspondence: Institute for Earth Systems Science and Policy, California State University Monterey Bay, Seaside, California 93955, USA.

E-mail: suzanne_worcester@monterey.edu
}

The few studies of hermit crab recruitment to date either have simply surveyed the abundance of small juveniles (e.g. Lowery \& Nelson 1988), have placed small shells out in the field at relatively calm sites (either buried in the sand, e.g. Asakura 1991, or in artificial tide pools, e.g. Nyblade 1974, J. Alio \& A. Kuris unpubl. data), or have quantified settlement in controlled laboratory conditions (Gherardi 1996). Each of these techniques has important limitations for quantifying hermit crab settlement, particularly on more energetic wave-exposed shores. Surveys of juvenile abundance may not accurately reflect larval availability and settlement rates at each site if there are differences in the availability or species composition of small shells or if there is substantial mortality between settlement and the age at which recruits are easily censused. Similarly, unconstrained introductions of shells cannot maintain a fixed composition and abundance of shells except under extremely calm conditions. Here we present a technique for monitoring hermit crab recruitment and for assessing the pattern of shell use by recently settled hermit crabs in even the most waveswept environments.

Study sites and methods. We conducted these studies at 10 sites along the California, USA, coastline in San Luis Obispo and Santa Barbara Counties $\left(34^{\circ} 23^{\prime} \mathrm{N}, 119^{\circ} 42^{\prime} \mathrm{W}\right.$ to $\left.35^{\circ} 13^{\prime} \mathrm{N}, 120^{\circ} 51^{\prime} \mathrm{W}\right)$ from June 1995 to October 1996. The common hermit crab species which occur along this stretch of coastline include Pagurus hirsutiusculus (2 subspecies; Crain \& McLaughlin 1993), P. samuelis, and P. granosimanus (Morris et al. 1980). The focus of these experiments was on the recruitment of $P$. hirsutiusculus, because this species was by far the most common and had the greatest number of new recruits in the field (authors pers. obs.). The chosen sites varied greatly in the abundance of $P$. hirsutiusculus (Table 1). Adult $P$. hirsutiusculus are most commonly found in shells from 
Table 1 Pagurus hirsutiusculus. Mean number of hermit crabs per square meter ( $\pm 95^{\prime \prime}$ c confidence limits) at each of the 10 field sites. We estimated hermit crab densities by counting the number of crabs in $0.25 \mathrm{~m}^{2}$ quadrats placed every $2 \mathrm{~m}$ along transects run honzontally through the midintertidal zone at each site. The number of quadrats sampled is given in the third column

\begin{tabular}{|lcc|}
\hline Site & Crab density & No. of quadrats \\
\hline Alegria & $2.7 \pm 3.0$ & 9 \\
Arroyo Hondo & $0 \pm 0$ & 6 \\
Coal Oil Point & $0 \pm 0$ & 10 \\
Diablo Cove & $24.8 \pm 13.6$ & 10 \\
Field's Cove & $32.0 \pm 8.0$ & 12 \\
Jalama & $4.0 \pm 3.9$ & 15 \\
Lompoc Landing & $1.1 \pm 2.0$ & 11 \\
North Vandenberg & $1.8 \pm 1.4$ & 10 \\
Shell Beach & $12.7 \pm 9.3$ & 17 \\
Shoreline Park & $23.2 \pm 17.4$ & 20 \\
\hline
\end{tabular}

Olivella biplicata and Acanthina spirata (Morris et al. 1980).

We tried a variety of techniques to assay the recruitment of hermit crabs to microgastropod shells that failed before using the simple approach of placing shells in a mesh bag. The holes in the mesh need to be small enough to retain the shells used by settling crabs, but large enough to permit entrance by megalopae seeking shells. For the species of crabs and shells in this system, polyester mesh (mesh diameter $=1.7 \mathrm{~mm}$ polyester netting \#9622, Research Nets Inc.) proved effective. To quantify hermit crab recruitment rates, we placed 50 small shells ( $\sim 2-3$ mm diameter) in bags made of $30 \times 30 \mathrm{~cm}$ squares of the polyester mesh. Each mesh square was folded to form a pouch, then securely closed with a cable tie and affixed to the substratum with cable ties looped through eye bolts screwed into plastic wall anchors in the rock. We placed 10 mesh bags at each of the 10 sites to assess whether the bags collected hermit crab recruits

We replaced the mesh bags either bi-weekly or monthly from June 1995 to October 1996. The number of hermit crab recruits and the shell type occupied by each crab in each bag was determined in the lab on the day the bags were collected in the field. We identified all crabs to species and all occupied shells to genus. Settling hermit crabs within 2 molts of the megalopal stage were often difficult to distinguish at the species level. Therefore, we retained the youngest crabs in individual running seawater containers in the lab with an abundant supply of larger shells until they had molted into a stage where they were identifiable to species (usually after 2 molts).

To test whether recruitment into the mesh bags was similar to 'natural' recruitment into unrestrained shells in surrounding tidepools, we censused the number of hermit crab recruits in 2 tidepools at each site every 3 to 4 mo. We collected a minimum of 75 to 100 crabs at each site (except at Arroyo Hondo where crabs were too rare) to quantify the size frequency distributions of crabs. As part of a larger study, we sorted the crabs into 6 size classes based on shell diameter $(<3,3-6,6-10$, $10-15,15-20,20-25$, and $>25 \mathrm{~mm})$, and separated them based on hermit crab species and occupied shell species. We quantified the overall density of hermit crabs at each site by running transects through the middle intertidal zone and counting all hermit crabs in $0.25 \mathrm{~m}^{2}$ quadrats. The recruit density of crabs at a site was measured as the proportion of recruits (crabs in shells $<6 \mathrm{~mm}$ ) from the size frequency distributions times the average density of crabs from the quadrats.

Our initial focus was on trying to measure recruitment rates of hermit crabs at different sites, so we haphazardly collected microgastropod shells to place in the bags. The preliminary settlement patterns, however, suggested that megalopae may be quite selective in their use of different shells. The recruitment bags contained a relatively haphazard mixture of shell types. Bags contained primarily shells of (93 to 98\%) Lacuna sp. and Littorina sp. (by far the most abundant 2-3 mm size snails in these habitats; authors' pers. obs.), but we also included some shells of much less common snail species such as Tricolia sp., Alia sp., Epitonium sp. and Homolapoma sp. (all species combined 2 to $7 \%$ ). The 'commonness' of shells was assessed by our difficulty in finding the snails in the field. After many days of searching we were unable ever to collect large numbers of shells of Tricolia sp., Alia sp., Epitonium sp. or Homolapoma sp. (Homolapoma sp. in particular was extremely difficult to collect.) On the other hand, thousands of Littorina sp. and Lacuna sp. could be collected with a sweep of a hand at most sites.

Results. Pagurus hirsutiusculus recruited to mesh bags in densities ranging from 0 to 29 recruits per bag (mean $\pm \mathrm{SD}=0.5 \pm 1.8$ for all sites and sample dates). Settlement density varied greatly over the year with the highest recruitment occurring between May and November (Fig. 1). The seasonal patterns for the site with the highest rate of recruitment (Field's Cove) is shown in Fig. 1. Almost no recruitment occurred in the winter. The seasonal pattern of recruitment in the bags mirrored the observations of recruits on the shore. Small juvenile crabs were typically observed on the shore 1 to 2 mo following peaks of settlement to shells in the bags.

Settlement densities also varied substantially among sites. The range of recruit densities among sites spanned more than 2 orders of magnitude, with highest settlement at Field's Cove (max. 129 recruits per month) and lowest settlement at Jalama (max. 1 recruit per month). This large spatial variation provided a 


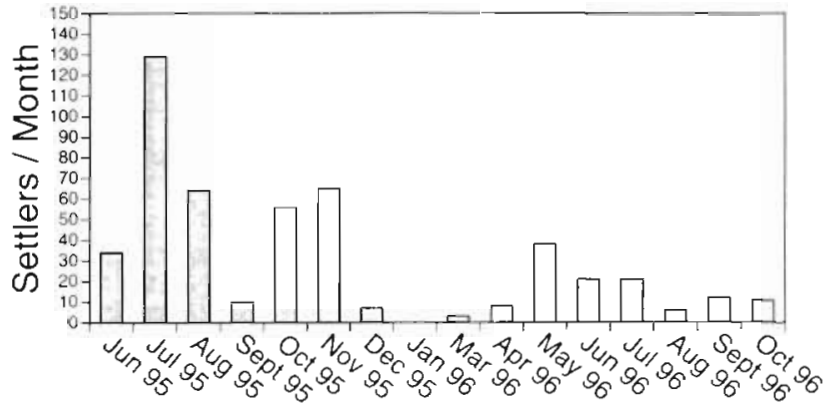

Fig. 1. Pagurus hirsutiusculus. Monthly fluctuation in recruitment into bags at the site with the highest recruitment (Field's Cove)

strong test for the ability of the bags to measure recruitment rates. The average density of recruits in the mesh bags at each site was highly correlated with densities of naturally occurring hermit crab recruits ( $\mathrm{r}=0.97$ ) censused on the shoreline (Fig. 2).

Pagurus hirsutiusculus recruits were quite selective in their choice of shells. They did not choose shell types in proportion to their availability in the bags ( $G$-test; $G=992.8, \mathrm{df}=5, \mathrm{p}<0.0001$ ). Indeed, when given a collection of shell types that roughly mirrored the availability of natural shells, hermit crabs preferred some of the shell species that were the least abundant (Table 2). Homolapoma sp. and Alia sp., in particular, were used much more frequently than would be predicted by their availability in the bags. In each case the proportion of $P$. hirsutiusculus recruits using these species was 5 to 10 times higher than one would have predicted on the basis of random settlement. Although only $2 \%$ of shells had recruits in the total study, nearly $20 \%$ of Homolapoma shells had hermit crab recruits. By contrast, Lacuna sp. and Littorina sp. were used much less frequently than one would expect by

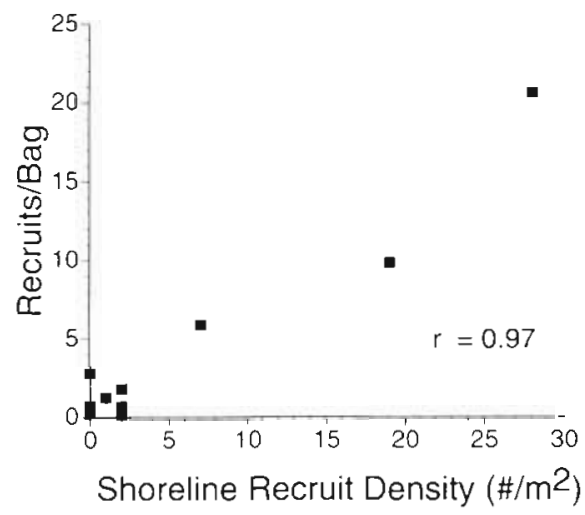

Fig. 2. Pagurus hirsutiusculus. Relationship between the densıty of recruits on the shoreline versus recruitment rate measured in bags for 10 sites
Table 2. Pagurus hirsutiusculus. Percent of each shell species chosen by settling hermit crabs compared to the percent of each shell species available to the crabs in mesh bags. The 3 columns in the table are: (1) the \% of the total pool of shells in the bags represented by each species; (2) the \% of all hermit crab recruits that used each shell species; and (3) the \% of shells of each species with hermit crab recruits. A total of 45968 shells were available, and $653 \quad P$. hirsutiusculus recruited. This yields an average of $1.4 \%$ of shells used by recruits across all species of shells

\begin{tabular}{|lccc|}
\hline Shell type & $\begin{array}{c}\text { \% of shells } \\
\text { in bags }\end{array}$ & $\begin{array}{c}\% \text { of recruits } \\
\text { using shell }\end{array}$ & $\begin{array}{c}\% \text { of shells used } \\
\text { by recruits }\end{array}$ \\
\hline Alid sp. & 1.6 & 5.4 & 4.8 \\
Epitonium sp. & 0.4 & 0.8 & 3.1 \\
Homolapoma sp. & 0.3 & 3.5 & 18.3 \\
Lacuna sp. & 69.2 & 60.3 & 1.2 \\
Littorina sp. & 23.4 & 20.5 & 1.3 \\
Tricolia sp. & 5.1 & 9.5 & 2.6 \\
\hline
\end{tabular}

chance. These were the most common small shells available in the field. The preferred shell types (Homolapoma sp. and Alia sp.) appeared to be much less abundant based on the difficulty we had locating these shell types in the field.

Discussion. Mesh bags with appropriately sized microgastropod shells provide an easy means to quantify hermit crab recruitment in rocky intertidal habitats. They are inexpensive to make and easy to deploy in the field. Most importantly, they appear to accurately measure the pattern of recruitment variation over space and time. This should permit detailed studies of the contribution of megalopal and juvenile patterns to the dynamics of hermit crab populations.

Shell selectivity is one of the most interesting possibilities for further study of megalopal and juvenile hermit crabs. Given the selectivity of adult hermit crabs for different shells, it is not surprising that we found evidence for non-random shell selection in juveniles of this species. Since Pagurus hirsutiusculus recruits preferred shells that are quite rare (as defined by our ability to find them), shell limitation may occur at these very early stages. If so, there may be cascading effects of resource limitation at these early stages that determine the distribution and abundance of adult hermit crabs. Using the technique described here, it is now feasible to study such issues with studies and experiments on hermit crab recruits in the field.

Acknowledgements. We thank the many people who helped with the field and laboratory work, especially C. Krenz. M. Blagborne, R. Louis, J. Colborn, R. Finke, S. Adams S. Cannon, T Jenkins, C. Blanchette, and S. Navarrete. We thank the Hollister Ranch Association for granting access to the Alegria site; Pacific Gas and Electric for granting access to the Diablo Cove and Field's Cove sites; and J. Carroll and $J$. Steinbeck of Tenera Environmental Services and L. John- 
son for ideas and assistance. We also thank 3 anonymous reviewers. This research was supported by grants from the Department of Energy's (DOE) National Institute for Global Environmental Change (NIGEC) through the NIGEC Western Regional Center at the University of Calufornia, Davis, the A. W. Mellon Foundation and the National Science Foundation (OCE-9402690) to S.G.

\section{LITERATURE CITED}

Asakura A (1991) Population ecology of the sand-dwelling hermit crab Diogenes nitidimanus. IV Larval settlement Mar Ecol Prog Ser 78:139-146

Bertness M (1980) Shell preference and utilization patterns in littoral hermit crabs of the Bay of Panama. J Exp Mar Biol Ecol 48:1-16

Bollay M (1964) Distribution and utilization of gastropod shells by the hermit crab Pagurus hirsutiusculus at Pacific Grove, California. Veliger (Suppl) 6:71-76

Crain JA, McLaughlin PA (1993) Larval, postlarval, and early juvenile development in Pagurus venturensis Coffin 1957 (Decapoda: Anomura: Paguridae) reared in the laboratory, with a redescription of the adult. Bull Mar Sci 53: $985-1012$

Elwood RW, Marks N, Dick JTA (1995) Consequences of shell-species preferences for female reproductive success

Editorial responsibility: Ronald Karlson (Contributing Editor), Newark, Delaware, USA in the hermit crab Pagurus bernhardus. Mar Biol 123: $431-434$

Gherardi F (1996) Gastropod shells or polychaete tubes? The hermit crab Discorsopagurus schmitti's housing dilemma. Ecoscience 3:154-164

Gherardi F, Zatteri F, Vannini M (1994) Hermit crabs in a mangrove swamp: the structure of Clibanarius laevimanus clusters. Mar Biol 121:41-52

Hazlett BA (1981) The behavioral ecology of hermit crabs. Annu Rev Ecol Syst 12:1-22

Kellogg CW (1976) Gastropod shells: a potentially limiting resource for hermit crabs. J Exp Mar Biol Ecol 22:101-111

Lowery WA, Nelson WG (1988) Population ecology of the hermit crab Clibanarius vittatus (Decapoda: Diogenidae) at Sebastian Inlet, Florida. J Crustac Biol 8:548-556

Mesce KA (1993) The shell selection behaviour of two closely related hermit crabs. Anim Behav 45:659-671

Morris RH, Abbott DP. Haderlie EC (1980) Intertidal invertebrates of California. Stanford University Press, Stanford

Nyblade CF (1974) Coexistence in sympatric hermit crabs. $\mathrm{PhD}$ dissertation, University of Washington, Seattle

Scully EP (1979) The effects of gastropod shell availability and habitat characteristics on shell utilization by the intertidal hermit crab Pagurus longicarpus. J Exp Mar Biol Ecol 37:139-152

Vance RR (1972) Competition and mechanism of coexistence in three sympatric species of intertidal hermit crabs. Ecology 53:1062-1074

Submitted: March 6, 1997; Accepted: July 18, 1997

Proofs received from author(s): September 22, 1997 